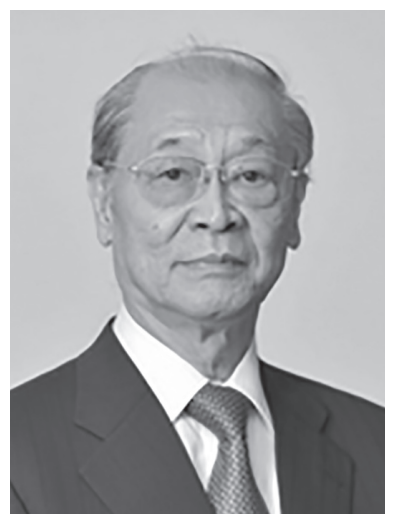

国際医療福祉大学医学部 学事顧問・教授

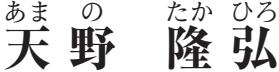

\author{
1970年 3 月 慶應義塾大学医学部 卒業 \\ 1975年 3 月 慶應義塾大学医学部大学院 (内科学専攻) 修了 \\ 1986年 2 月 慶應義塾大学医学部専任講師（～2003年 6 月） \\ 2003年 9 月 慶應健康相談センター (慶應大学人間ドック施設) センター長（～2009年 3 月) \\ 2005年 7 月 慶應義塾大学医学部教授（～2009年 3 月） \\ 2009年 4 月＼cjkstart慶応義塾大学客員教授（～現在) \\ 2009年 4 月 国際医療福祉大学臨床研究センター教授（～2017年 3 月） \\ 2009年10月 山王メデイカルセンター院長（～2014年 3 月） \\ 2014年 4 月 山王メディカルセンター名誉院長（～現在） \\ 2015年 1 月 国際医療福祉大学 大学院長（～2017年 5 月） \\ 2015年 4 月 国際医療福祉大学 副学長（～2018年 3 月) \\ 2017年 4 月 国際医療福祉大学 医学部教授（～現在） \\ 2018年 4 月 国際医療福祉大学 学事顧問（～現在）
}

\section{【学会役員等】}

日本医学教育学会 元理事、名誉会員

日本神経学会 元評議員、卒前卒後教育委員会委員、専門医、指導医

日本脳卒中学会 元理事、名誉会員、認定専門医、指導医

脳ドック学会 元評議員

日本ドック学会 社員、認定医、元理事

日本総合健診医学会 審議員、理事

人間ドック健診専門医、指導医 


\title{
データを発信する健診機関側の作業上の問題点と 今後のメリット
}

\author{
国際医療福祉大学医学部 学事顧問・教授 \\ あまの野 隆引能
}

2019年度から日本総合健診医学会と人間ドック学会が合同で人間ドック・健診 用語集の作成が行わ れ、ドック基本検査項目である心電図、眼底カメラ、胸部 $\mathrm{X}$ 線、上部消化管 $\mathrm{X}$ 線、腹部超音波検查、上 部消化管内視鏡などの画像検査の用語が検討され2020年 5 月に発表された。演者は、健診機関として 2003年から大学病院のドック健診部門、ついで2009年から現センターで今に至るまで長年ドック健診 に関与してきた。また、1988年に産業医制度が発足以来、一部上場会社の産業医を務めてきた。これ らの経験から、本発表では、必要な画像の用語集完成が今後ドック健診実施側と、産業医側に、どの ようなメリットをもたらすか、さらに作業上での問題点を考えてみたい。

ドック健診施設では、画像基本項目に加え各種の血液検査・検尿・検便などの検査が行われる。得 られた検査データは自動的に、あるいは検査所見用紙に記入され手入力が行われる。中には、発生源 入力でコンピュータ画面に入力される。このデータは各検査機関でまちまちのコンピューターソフト を通して判定され、コメントがつけられ受診者に報告書が拉くられる。

一方、企業健診を兼ねているドック健診ではデータが電子ファイルや打ち出し用紙で企業に提出さ れる。企業は、多くは業者により法的に定められた項目を入力し、定められた形式として企業、健保 組合側から報告される。

各健診機関では、現行の用語などのデータで一見なんら問題は無さそうであるが、複数の各種健診 機関から異なった用語、基準值のデータが集まる企業側としては、その判定、問題項目の洗い出しに 混乱がおきる。産業医がばらばらの用語や検查基準值を、医師として判断し問題デー夕の抽出、判定 作業におわれる。各企業から報告されたデータでは、ビックデータとしての解析に混乱、ばらつきが あり、ビックデータ分析の精度に問題をもたらす。このように考えると、今回の用語の統一で、時間 がかかるものの共通用語の使用へと進むことが望まれる。用語だけでなく、検査基準值の共用化も長 年の懸案事項であった。2019年に日本臨床検査標準協議会が中心になり、基準範囲共用化の適応拡大 もはじまった。産業医活動として、問題となる有所見者を大きな病院施設へ紹介し、二次利用される 際にも、定まった用語の使用は基準值の共通化と相まって、そのメリットは極めて大きい。

このような、日本全体でのドック健診機関が、画像検査に共通の用語を使用することは、共用基準 值の採用と相まって、その意義は極めて大きい。

健診施設では、今回発表された用語へと進むには、ソフトの改修、手入力の検査所見用紙などの改 修が必要である。用語の変換、改修には、用語変換ソフトの導入法と、各健診機関で使用するソフト を根本的に改修する方法がある。画像検査部門での入力用語を変え、同時に共用基準值に対応するこ とを目指して、我々は後者の方法に取りかかっている。新たな用語の統一化が健診機関すべてに行き 渡るにはなお時間要し、またソフト改修のためのコストも発生する。しかし、受診者である日本国民 にもその利便性が高まり、共通用語と共用基準範囲の使用でビックデータ分析の精度があがる。その 結果、国民の健康維持・増進の戦略をねる基本ビックデー夕になる。今や、その方向へと歩み出すこ とが求められている。 